\title{
Boundaries of the City
}

In this study Alan Waterhouse draws on anthropology, social and cultural history, literature, and philosophy to reach an understanding of the roots of Western architecture and city building. He explores the illusion that cities are constructed to impose rational order, an order articulated through urban boundaries. These boundaries, he finds, are shaped around our instinctive fears and insecurities about crime, insurrection, and the violent disruption of everyday life. At the same time, contrary instincts aspire to create a unified domain, to proclaim the interdependence of things through constructed work. Cities are shaped less by rational design than by a recurring dialectic of boundary formation.

These impulses underlie the formal vocabulary of architecture and urbanism. Waterhouse follows them through the theories, ideologies, and styles that seem to govern city building; he finds their presence in the creation of territorial divisions, and also wherever the cityscape has been shaped by a poetic imagination.

Tracing his narrative of urban boundaries from antiquity to the birth of modernism, Waterhouse discovers some stubborn legacies that bind contemporary urban design to the past. Part One explores the boundary dialectic in our regard for deities, for nature, and for one another, and then as a powerful influence on architectural invention and our ways of life. Part Two traces these themes through city building history, to show how architecture and human relatedness are subordinated by boundary formation in the cycles of urbanization.

ALAN WATERHOUSE is professor of urban planning in the Department of Geography, University of Toronto. He is author of Visual Change in Cities. 
This page intentionally left blank 

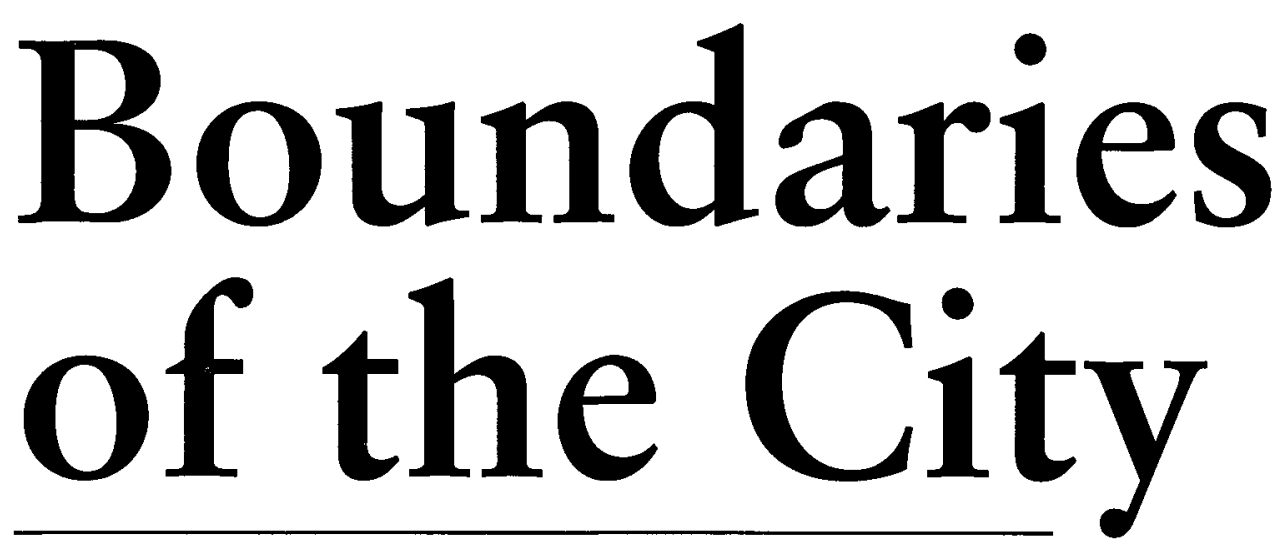

The Architecture

of Western

Urbanism

Alan Waterhouse

UNIVERSITY OF TORONTO PRESS

Toronto Buffalo London 
(C) University of Toronto Press Incorporated 1993

Toronto Buffalo London

Printed in Canada

ISBN 0-8020-0538-1

(6)

Printed on acid-free paper

\section{Canadian Cataloguing in Publication Data}

Waterhouse, Alan

Boundaries of the city : the architecture of

western urbanism

ISBN 0-8020-0538-1

1. City planning - Europe - History. 2. Architecture

- Europe - History. 3. Urbanization - Europe -

History. I. Title.

NA9183.W37 $1993 \quad 711^{\prime} .4^{\prime} 094 \quad$ C93-094070-9

This book has been published with the help of a grant from the Social Science Federation of Canada, using funds provided by the Social Sciences and Humanities Research Council of Canada. Publication was also assisted by a generous grant from the University of Toronto Women's Association. 
For Sandra 
This page intentionally left blank 